\title{
Conceptual Elements: A Detailed Framework to Support and Assess Student Learning of Biology Core Concepts
}

Tawnya Cary ${ }^{\dagger}$ and Janet Branchaw ${ }^{t+*}$

'Wisconsin Institute for Science Education and Community Engagement and ₹Department of Kinesiology, University of Wisconsin-Madison, Madison, WI 53706

\begin{abstract}
The Vision and Change in Undergraduate Biology Education: Call to Action report has inspired and supported a nationwide movement to restructure undergraduate biology curricula to address overarching disciplinary concepts and competencies. The report outlines the concepts and competencies generally but does not provide a detailed framework to guide the development of the learning outcomes, instructional materials, and assessment instruments needed to create a reformed biology curriculum. In this essay, we present a detailed Vision and Change core concept framework that articulates key components that transcend subdisciplines and scales for each overarching biological concept, the Conceptual Elements (CE) Framework. The CE Framework was developed using a grassroots approach of iterative revision and incorporates feedback from more than 60 biologists and undergraduate biology educators from across the United States. The final validation step resulted in strong national consensus, with greater than $92 \%$ of responders agreeing that each core concept list was ready for use by the biological sciences community, as determined by scientific accuracy and completeness. In addition, we describe in detail how educators and departments can use the CE Framework to guide and document reformation of individual courses as well as entire curricula.
\end{abstract}

\section{INTRODUCTION}

The Vision and Change in Undergraduate Biology Education: Call to Action report (American Association for the Advancement of Science, 2011) calls for undergraduate biology educators to develop students' understanding of core concepts across biological scales and to develop students' ability to synthesize information in ways that connect conceptual domains (National Research Council [NRC], 2009). The report recommends that biology educators structure undergraduate teaching around five core concepts, which we focus on here, and six core competencies. The Vision and Change core concepts (pathways and transformations of energy and matter [PTEM], information flow, storage and exchange [IFES], structure and function [SF], evolution [E], systems $[S]$ ) emerged from decades of effort within the biology education community to identify and define the overarching concepts essential for understanding biology (e.g., NRC, 2003; Klymkowsky, 2010; Scheiner, 2010; Quinn et al., 2011; for more, see Table 1 in Brownell et al., 2014). Though the five core concepts offer a comprehensive profile of biology, they are so broad that it can be challenging for biology educators to unpack their complexity in ways that allow them to be used to write learning objectives, design instructional materials, and develop aligned assessments.

To begin unpacking this complexity, Brownell and colleagues developed the BioCore Guide, which offers subdisciplinary interpretations of the Vision and Change core concepts (Brownell et al., 2014). The BioCore Guide outlines a few general overarching principles defining each core concept and defines several subconcepts within
Michèle Shuster, Monitoring Editor Submitted October 17, 2016; Revised January 5, 2017; Accepted January 12, 2017

CBE Life Sci Educ June 1, 2017 16:ar24

DOI:10.1187/cbe.16-10-0300

*Address correspondence to: Janet Branchaw (branchawawisc.edu).

(C) 2017 T. Cary and J. Branchaw. CBE-Life Sciences Education @ 2017 The American Society for Cell Biology. This article is distributed by The American Society for Cell Biology under license from the author(s). It is available to the public under an Attribution-Noncommercial-Share Alike 3.0 Unported Creative Commons License (http://creativecommons.org/licenses/ by-nc-sa/3.0)

"ASCB®" and "The American Society for Cell Biology $\circledR^{\prime \prime}$ are registered trademarks of The American Society for Cell Biology. 
TABLE 1. CE Framework of the Vision and Change core concepts ${ }^{\mathrm{a}}$

Pathways and transformations of energy and matter (PTEM)

PTEM1: Energy is neither created nor destroyed, but can be transformed from one form to another to generate biological activity.

PTEM2: Input of energy, which can be from different sources, is needed to build and maintain biological entities, thereby lowering entropy in the system.

PTEM3: Biological entities harness potential energy stored in electrochemical gradients and released from chemical reactions.

PTEM4: Matter is recycled through the rearrangement of chemical bonds in biological entities.

PTEM5: Biological entities regulate the synthesis, storage, and mobilization of biological compounds to meet energy demands.

PTEM6: Many chemical elements can serve as electron donors and acceptors to drive biological processes.

PTEM7: Matter can transfer between the abiotic and biotic components of biological systems.

\section{Information flow, exchange, and storage (IFES)}

IFES1: Information exists in many forms and is relayed within and across biological molecules, cells, tissues, organisms, populations, and ecosystems.

IFES2: Genetic information is stored in nucleic acids (DNA and RNA); epigenetic information is stored in proteins that associate with DNA and in reversible DNA modifications.

IFES3: The process of protein synthesis results from the flow of genetic information through various pathways.

IFES4: Information from the environment regulates protein synthesis and activity, which control cellular processes and thereby organismal and population-level activity.

IFES5: Organisms transmit genes and epigenetic information to their offspring.

\section{Structure and function (SF)}

SF1: Biological structures from the molecular to the ecosystem scale, and their interactions are determined by chemical and physical properties that both enable and constrain function.

SF2: Individual structures can be arranged into organized units that enable more complex functions.

SF3: Structural features of biological entities undergo changes during development that are determined by the regulation of gene expression.

SF4: Structural features are dynamic and modifications can be made in response to environmental changes that are compensatory to restore lost function or noncompensatory to eliminate functions that are no longer needed.

SF5: Comparable changes in structure can have small or large effects on function, depending on the spatial location.

Evolution (E)

E1: All living organisms share common ancestors at some time in the past.

E2: The phenotypes of living organisms result from the gain and loss of traits along their lineage.

E3: Genetic variation within a population can be generated by mutation, which results in the generation of novel traits, and by sexual recombination, endosymbiosis, and horizontal gene transfer.

E4: Phenotypes, based upon underlying genotypes and environmental factors, can be subject to selective pressure.

E5: Organisms have greater fitness if they have a phenotype that increases their ability to survive and reproduce in a particular environment.

E6: Populations are composed of individual organisms that vary in their fitness, leading to differential rates of survival and reproduction and therefore changes in allele frequency over time.

E7: Evolution in a population may be due to events not related to fitness, including genetic drift and gene flow.

E8: The rate of evolutionary change varies and is influenced by many factors, including mutation rate, generation time, and environmental variation.

E9: Speciation occurs when subpopulations can no longer exchange genetic material, allowing them to diverge over time in their physiological and ecological traits.

Systems (S)

S1: Biological entities interact through chemical and physical signals that can be transient, depend on spatial organization, and are influenced by environmental factors.

S2: Changes in one component of a biological system can affect or be regulated by other components of the same system.

S3. Biological systems can be defined at different scales, interact within and across scales, and together form complex networks.

S4: Biological systems include and are affected by biotic and abiotic factors in the environment.

S5: Interactions between and among biological entities can generate new system properties.

a“Entity" refers to an independent thing that contains in itself all the conditions essential to autonomy; that which forms a complete whole; biologically, denoting a separate and distinct structure at any scale (e.g., molecules, cells, organisms, ecosystems). Adapted from www.biology-online.org/dictionary/Entity.

subdisciplinary fields and their generally associated biological scales. The Conceptual Elements (CE) Framework presented here provides a more detailed comprehensive list of overarching principles that can be used as a tool to make connections across subdisciplines and scales (Table 1), thus complementing the
BioCore Guide's exploration of each core concept within subdisciplines and scales. Overall, the elements in the CE Framework were developed to construct a comprehensive understanding of each core concept across all biological scales and subdisciplines. We recognize that the development of a framework that is broad 
enough to encompass learning outcomes for the breadth of biology yet unencumbered with details is an especially lofty challenge (Dirks and Knight, 2016). We offer the detailed CE Framework here as a tool to be field-tested and invite the community to partner with us to refine it (see Next Steps in Development).

The generality of our approach is intentional and meant to address the need to support novice learners in understanding the breadth of biology by providing a foundation for students to organize their knowledge. With the CE Framework, educators can generate isomorphic learning objectives that span biological phenomena and help students make connections across subdisciplines to better understand how biology is not simply a jumble of facts that they must memorize. Novice thinkers generate linear connections between distinct bits of knowledge, while expert thinkers generate a network of connections that facilitate knowledge retrieval and transfer of knowledge to novel situations (Ambrose et al., 2010; Smith et al., 2013). Therefore, it is ideal to provide novice learners with tools to practice complex knowledge organization. The CE Framework, which provides common conceptual components across biology, can be used to guide the development of instructional tools that have the potential to build connections across a curriculum and move students toward expert thinking.

In addition, the broad approach provides flexibility in application of the CE Framework to meet user goals. In general, we highlight three primary areas for application: 1) developing instructional materials to support student learning, 2) developing and aligning learning objectives and assessments, and 3) evaluating existing curricula; however, we think further application is possible and left to the imagination of the user. First, the CE Framework offers enough detail to guide the development of instructional materials that focus on teaching the complexity of the five core concepts. Second, the CE Framework can guide the development and alignment of learning objectives and assessments that measure student learning of the five core concepts. Third, the CE Framework can provide a metric for evaluating the depth and breadth of core concept coverage of existing course objectives, instructional materials, and assessments across a curriculum, since it transcends biological subdisciplines and scales. Overall, the CE Framework can guide curricular reform efforts by documenting, comparing, and tracking progress of student learning of the core concepts across courses in an undergraduate biology curriculum, from introductory to advanced level. In addition, for departments pursuing Partnership for Undergraduate Life Sciences Education (PULSE) accreditation, the CE Framework can be used to generate evidence for their PULSE rubric rankings (Aguirre et al., 2013).

Here, we describe the development and validation of the CE Framework, including local field-testing as part of two biology education research projects and a national review by experts

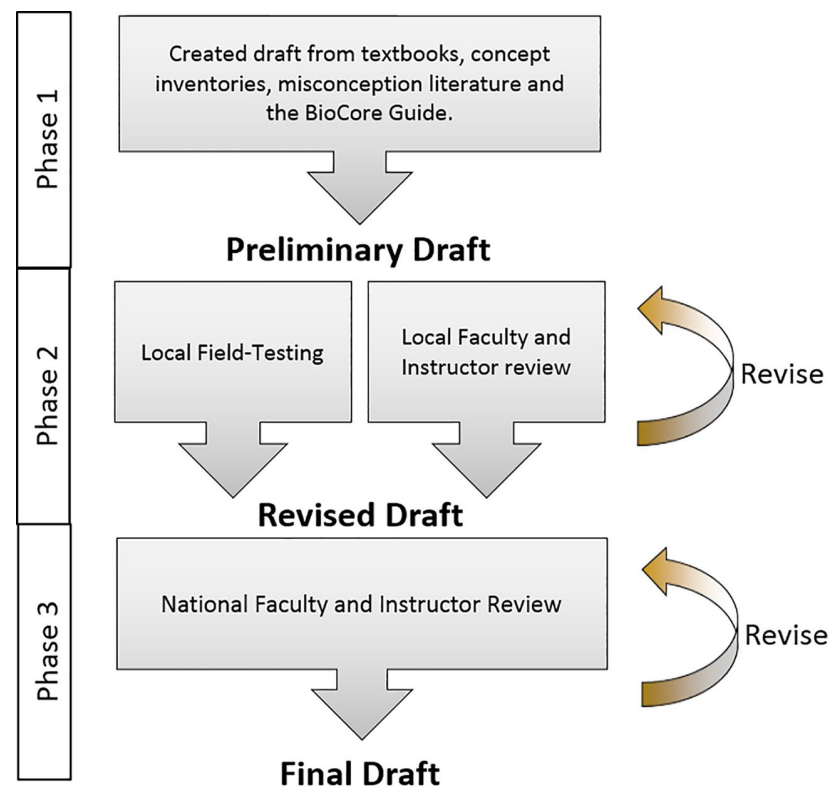

FIGURE 1. CE Framework development process. An overview of the iterative process of development, testing, review, and revision used to develop the CE Framework.

from a variety of subdisciplines that evaluated the CE Framework for scientific accuracy and completeness (Figure 1).

\section{DEVELOPMENT OF THE CE FRAMEWORK Phase 1: Exploring the Literature to Generate a Preliminary Draft}

To begin, we analyzed and integrated currently available resources designed to promote student conceptual understanding in biology. Specifically, we started with the principles of each core concept, as defined in the BioCore Guide (Brownell et al., 2014) and elaborated upon in the Essential Concepts for Biology (Dirks and Knight, 2016), and compared these with biological concepts presented in other available resources ranging from concept inventories to student misconceptions (Table 2). We gathered feedback from local biology experts with diverse subdisciplinary training and used a reductionist approach to identify key elements of each core concept that span biological scale and subdiscipline. We then wrote concise statements describing each conceptual element to produce a preliminary draft of the framework, which had a total of 33 conceptual elements (9-PTEM, 6-IFES, 4-SF, 9-E, 5-S). Each conceptual element for a single core concept represents one piece of a puzzle that must be interlaced with the other elements to construct a comprehensive understanding of that core concept.

TABLE 2. Biological resources used in the initial construction of the CE Framework

\begin{tabular}{|c|c|c|}
\hline Instructional references & Concept inventories & Misconception literature \\
\hline $\begin{array}{l}\text { - Campbell Biology, 9th ed. } \\
\text { (Reece et al., 2011) } \\
\text { - Biology, 3rd ed. } \\
\text { (Brooker et al., 2014) } \\
\text { - Biological Science } \\
\text { (Freeman et al., 2002) }\end{array}$ & $\begin{array}{l}\text { - General biology (Klymkowsky and } \\
\text { Garvin-Doxas, 2008; www.bioliteracy } \\
\text {. colorado.edu) } \\
\text { - } \text { Natural selection (Anderson et al., 2002) } \\
\text { - } \text { Genetics (Smith et al., 2008) } \\
\text { - } \text { Microbiology (Marbach-Ad et al., 2009) } \\
\text { - Molecular biology (Couch et al., 2015) }\end{array}$ & $\begin{array}{l}\text { - Physiology/metabolism (Michael, 1998; Michael et al., 1999; } \\
\text { Wilson et al., 2006) } \\
\text { - Evolution (Anderson et al., 2002; Klymkowsky et al., 2003; } \\
\text { Tanner and Allen, 2005; Nehm and Reilly, 2007; Williams } \\
\text { et al., 2008; Heitz et al., 2010) } \\
\text { - Ecology (D'Avanzo, 2003, 2008; Stamp and Armstrong, } \\
\text { 2005) }\end{array}$ \\
\hline
\end{tabular}


Phase 2: Local Review and Field-Testing

We recruited 14 local faculty members and biology instructors with expertise across a variety of biological subdisciplines to review the preliminary draft of elements and provide detailed feedback. We simultaneously conducted local field-testing while iteratively refining the CE Framework based on local reviewer feedback gathered through an online survey, one-onone meetings, and small focus groups. Each local reviewer independently reviewed the framework for scientific accuracy and completeness and was asked to provide feedback and suggestions in his or her area of expertise. Specifically, reviewers were asked to determine whether each list of elements was complete and, if not, to identify the missing elements. We also asked them to rate the scientific accuracy of the elements for each concept as low, medium, or high. If ratings of low or medium were given, reviewers were asked to explain the ratings and make suggestions for improvement.

Four to six local reviewers provided detailed feedback for each concept. At this stage of development, greater than or equal to $80 \%$ of the reviewers determined that the lists were complete for all concepts, except evolution (only 67\% agreement; Figure 2). Scientific accuracy was deemed as "medium" or "high" for all of the conceptual elements for each core concept, with "high scientific accuracy" ratings for each concept ranging from $50 \%$ to $83 \%$ (Figure 2 ). In addition, we asked these reviewers to provide biological examples from their areas of expertise that demonstrate individual conceptual elements. The examples were used 1) to validate whether the elements transcended biological subdisciplines and scales and 2) to refine the conceptual elements language so that it was general enough to be applied across subdisciplines.

To field-test the preliminary draft of the CE Framework for completeness and accuracy, we applied the framework in two biology education research projects that were focused on measuring student understanding of the Vision and Change core concepts. For each project, the CE Framework was used as a rubric to evaluate student-generated responses to open-ended questions. We evaluated the utility and completeness of the framework based on the robustness of the CE Framework to assess student understanding. The first project tested how well the CE Framework characterized the complexity of student responses when asked to explain what they knew about each core concept. The second project tested how well the CE Framework captured the complexity of student responses when asked to apply their knowledge of the core concepts to a specific biological phenomenon (manuscripts from these projects are in preparation). Overall, the CE Framework yielded systematic coding of student responses from multiple trained coders and allowed us to assess what students understood (or did not understand) about each concept.

However, some students' responses in these field tests could not be coded using the CE Framework. For these responses, we evaluated whether they represented misconceptions, inaccurate conceptions, or an element that was missing from the framework. After careful review, we determined that all of the noncoded answers were either misconceptions or inaccurate conceptions, and not missing elements. This suggested that, although the preliminary draft of the CE Framework needed revision, it was complete. The relative ease with which the framework could be applied successfully in these two projects with very different study aims suggested that the CE Framework did indeed describe fundamental building blocks that could be broadly applied in biology. At the end of this phase of development, the CE Framework still had a total of 33 conceptual elements, but PTEM was reduced by one element and one element was added to SF (8-PTEM, 6-IFES, 5-SF, 9-E, 5-S).

\section{Phase 3: National Review}

We recruited 48 experts in the biological sciences from across the nation to review the revised draft of the CE Framework and provide specific feedback on each element through an online survey. Of the reviewers, $81 \%$ were faculty members, $11 \%$ instructors, $1 \%$ professional staff, and $7 \%$ postdoctoral trainees. The majority (69\%) held positions at $\mathrm{PhD}$-granting institutions, and the remaining reviewers were at institutions that granted master's (15\%) and bachelor's (17\%) degrees. Eighty-nine percent had taught an introductory undergraduate biology course, and $72 \%$ had taught an upper-division undergraduate biology course in the past 3 years. The breadth and emphasis of the reviewers' areas of self-reported expertise is represented in Figure 3.

Reviewers were asked to rate each core concept and its list of elements for readiness for use by the biological sciences community (Figure 4). They were instructed to consider the scientific accuracy and completeness of the list of elements for each concept to determine their ratings. The vast majority of reviewers rated the revised draft as "ready" or "ready with minor revisions" for use by the community (PTEM: 96\%; IFES: 94\%; SF: 96\%; E: 96\%; S: 92\%). Consequently, the final number of elements for only two of the core concepts changed as a result of the national review. PTEM was reduced from eight to seven elements, and IFES was
FIGURE 2. Local review for completeness and accuracy of the preliminary draft of CE Framework. A total of 14 local experts provided ratings for (A) completeness (percent of reviewers that agreed the list of elements was complete) and (B) scientific accuracy of the preliminary draft of the conceptual elements. None of the reviewers rated the scientific accuracy as low. PTEM, pathways and transformations of energy and matter; IFES, Information flow, exchange, and storage; SF, structure and function; E, evolution; S, systems.
B)

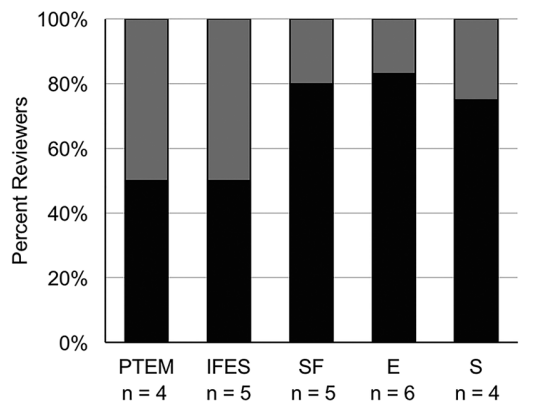

16:ar24, 4 


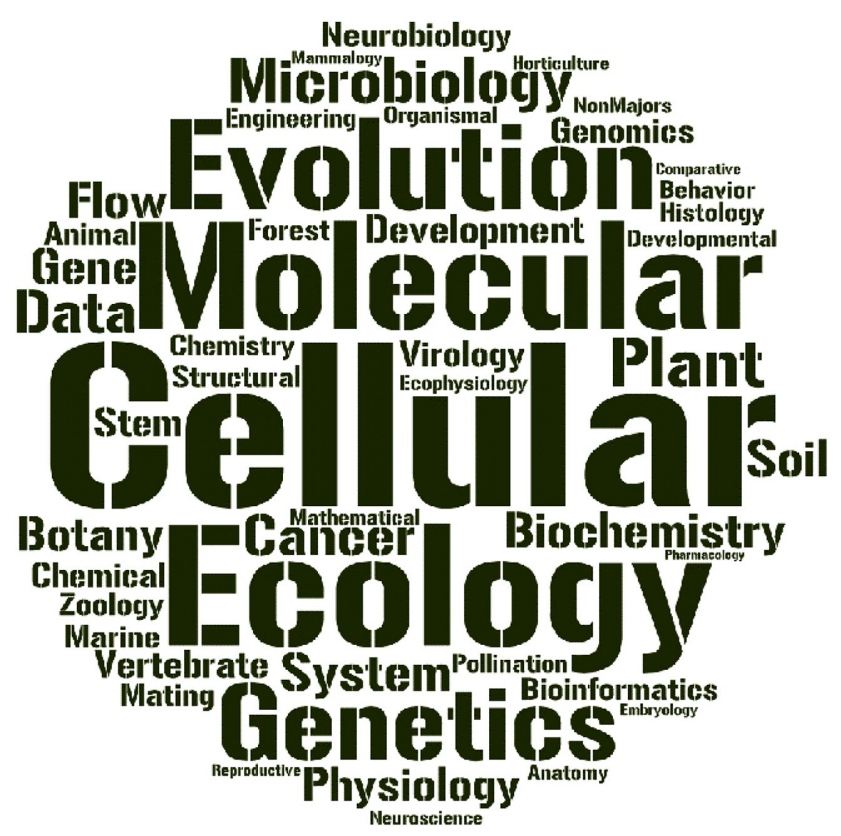

FIGURE 3. Disciplinary areas of expertise of national reviewers. All of the self-reported areas of expertise in the biological sciences are listed in this figure, except "biology" and "education," which were removed because they do not indicate a biological subdisciplinary area of expertise. The size of the text corresponds to the percentage of reviewers who identified each area of expertise (i.e., the larger the text size the greater the percentage).

reduced from six to five elements for a total of 31 elements in the final draft. However, for all core concepts, national reviewers made suggestions for minor changes in the language and suggestions to combine two elements into one or to divide a single element into two separate elements. We especially focused on suggestions from a few reviewers who rated the elements as needing major revisions, but all suggestions were used to generate the final framework. The specific suggestions for

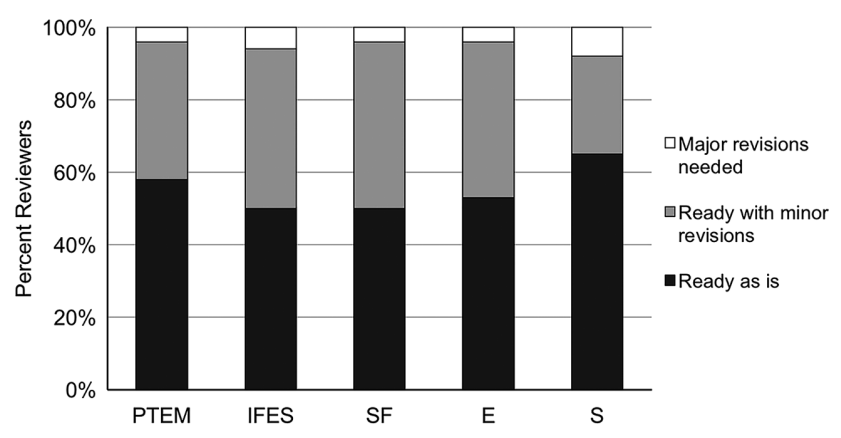

FIGURE 4. National review of the revised draft of CE Framework. A total of 48 experts from across the nation reviewed the second draft of the CE Framework. They provided an overall rating of the set of elements for each concept as "Ready as is," "Ready with minor revisions," or "Major revisions needed." They also provided specific feedback on each element for use in making final revisions. PTEM, pathways and transformations of energy and matter; IFES, Information flow, exchange, and storage; SF, structure and function; E, evolution; S, systems. improvement provided by the national reviewers were compiled, analyzed, and incorporated into the final list of key elements presented in Table 1 as the CE Framework.

\section{NEXT STEPS IN DEVELOPMENT}

Further refinement of the CE Framework will require feedback through national field-testing with faculty across a breadth of subdisciplines and at various types of institutions. We invite those interested in participating in such a study to contact us.

\section{USING THE CE FRAMEWORK}

Our motivation for developing the CE Framework was driven by our desire to operationalize the defined Vision and Change core concepts across biological subdisciplines for students enrolled in introductory biology. Although our initial application of this framework in local field-testing focused on assessment of student learning, we envision that individual instructors, departments, and institutions could use the CE Framework in a variety of ways. These include but are not limited to 1) developing instructional materials to support student learning, 2) developing and aligning learning objectives and assessments, and 3) evaluating existing curricula.

\section{Developing Instructional Materials to Support Student Learning}

As our ability to investigate biological systems becomes more sophisticated and our understanding of biological phenomena advances, we must train future biologists with the skills needed to tackle complex, interconnected biological questions (NRC, 1999; President's Council of Advisors on Science and Technology, 2012). We need to prepare students to transfer knowledge to new contexts, define complex problems in ways that can be investigated, and apply their problem-solving skills to realworld challenges (Woese, 2004; Goldenfeld and Woese 2007). Although most introductory biology instructors strive to engage students with higher-order thinking, a study by Momsen et al. (2010) showed that the majority of introductory biology courses rely on rote memorization. We propose that educators can use the CE Framework as an instructional tool in introductory biology and throughout a curriculum to help students identify, understand, and apply the core concepts as a means of promoting higher-order thinking.

One example of the way that the CE Framework could be used to foster conceptual thinking is to have students use it to guide identification of the core concepts and the specific key elements represented in a newly presented biological phenomenon. In Table 3, we present three biological phenomena and provide three conceptual elements that align with each phenomenon as an example of how this could work in the classroom. Students could be asked to generate an explanation of a biological phenomenon individually or as a group and then to use the CE Framework to identify all of the elements present in their descriptions. In this way, they will practice linking specific knowledge and facts about the phenomenon to the general principles represented in the elements.

Instructors might also ask students to use the conceptual elements to make connections with material that they have learned in other courses across a curriculum, thereby supporting integration of learning across subdisciplines and biological scales. In Table 4, we demonstrate how the conceptual elements provide 
TABLE 3. Examples of complex biological phenomena ${ }^{a}$

\begin{tabular}{|c|c|c|}
\hline Complex biological phenomenon & Core concepts & Conceptual elements \\
\hline $\begin{array}{l}\text { Homeostatic regulation of blood } \\
\text { glucose levels }\end{array}$ & $\begin{array}{l}\text { Information flow, exchange, } \\
\text { and storage; pathways } \\
\text { and transformations of } \\
\text { energy and matter; and } \\
\text { systems }\end{array}$ & $\begin{array}{l}\text { IFES4: Information from the environment regulates protein synthesis and } \\
\text { activity, which control cellular processes and thereby organismal and } \\
\text { population-level activity. } \\
\text { PTEM5: Biological entities regulate the synthesis, storage, and mobiliza- } \\
\text { tion of biological compounds to meet energy demands. } \\
\text { S2: Changes in one component of a biological system can affect or be } \\
\text { regulated by other components of the same system. }\end{array}$ \\
\hline $\begin{array}{l}\text { Countercurrent gas exchange in } \\
\text { fish }\end{array}$ & $\begin{array}{l}\text { Structure and function; } \\
\text { information flow, } \\
\text { exchange, and storage; } \\
\text { and systems }\end{array}$ & $\begin{array}{l}\text { SF2: Individual structures can be arranged into organized units whose } \\
\text { emergent properties enable more complex functions. } \\
\text { IFES3: The genetic code regulates the process of protein synthesis and } \\
\text { determines the structure and function of proteins. } \\
\text { S2: Changes in one component of a biological system can affect or be } \\
\text { regulated by other components of the same system. }\end{array}$ \\
\hline $\begin{array}{l}\text { Coevolution of the symbiotic } \\
\text { relationship among three-toed } \\
\text { sloths, pyralid moths, and } \\
\text { green algae }\end{array}$ & $\begin{array}{l}\text { Evolution; systems; } \\
\text { and pathways and } \\
\text { transformations of energy } \\
\text { and matter }\end{array}$ & $\begin{array}{l}\text { E6: Populations are composed of individual organisms that vary in their } \\
\text { fitness, leading to differential rates of survival and reproduction and, } \\
\text { therefore, changes in allele frequency over time. } \\
\text { S2: Changes in one component of a biological system can affect or be } \\
\text { regulated by other components of the same system. } \\
\text { PTEM4: Matter is recycled through the rearrangement of chemical bonds } \\
\text { by biological entities. }\end{array}$ \\
\hline
\end{tabular}

${ }^{a}$ Each example includes elements from multiple concepts. The conceptual elements can be used to dissect the complexity in order to assess student understanding of the components and the connections between components.

a common infrastructure that can be used to connect examples of biological phenomena that are typically taught in different undergraduate biology courses, yet address the same conceptual elements. An exercise in which students are provided examples from a current and previous course and then asked to con- nect them using the CE Framework could be used to help students make connections between courses. Beyond individual courses, this type of exercise may be used in a capstone course, where examples relevant to a complex problem could be taken from different courses across a curriculum. Students could be

TABLE 4. Selected conceptual elements taught across biological scales within a curriculuma

\begin{tabular}{|c|c|c|c|}
\hline Selected conceptual elements & Molecular biology & Organismal biology & Ecological biology \\
\hline $\begin{array}{l}\text { PTEM5: Biological entities regulate the } \\
\text { synthesis, storage and mobilization } \\
\text { of biological compounds to meet } \\
\text { energy demands. }\end{array}$ & $\begin{array}{l}\text { The processes of glycogenesis, } \\
\text { glycogenolysis, and } \\
\text { gluconeogenesis }\end{array}$ & $\begin{array}{l}\text { Targeted delivery of glucose by } \\
\text { the cardiovascular system to } \\
\text { metabolizing cells }\end{array}$ & $\begin{array}{l}\text { Rhizobial soil bacteria live } \\
\text { inside plant root nodules } \\
\text { and fix nitrogen used by the } \\
\text { plant }\end{array}$ \\
\hline $\begin{array}{l}\text { IFES1: Information exists in many } \\
\text { forms and is relayed within and } \\
\text { across biological molecules, cells, } \\
\text { tissues, organisms, populations, and } \\
\text { ecosystems. }\end{array}$ & $\begin{array}{l}\text { Environmental cadmium signals } \\
\text { trigger synthesis of } \\
\text { cadmium-binding peptides }\end{array}$ & $\begin{array}{l}\text { Thyroid hormone regulation of } \\
\text { tadpole development and } \\
\text { metamorphosis }\end{array}$ & $\begin{array}{l}\text { Light-dark cycle regulation of } \\
\text { seasonal flowering in plants }\end{array}$ \\
\hline $\begin{array}{l}\text { SF2: Individual structures can be } \\
\text { arranged into organized units that } \\
\text { enable more complex functions. }\end{array}$ & $\begin{array}{l}\text { Quarternary structures of } \\
\text { protein subunits (e.g., } \\
\text { hemoglobin) }\end{array}$ & $\begin{array}{l}\text { Smooth muscle filament } \\
\text { arrangement in the walls of } \\
\text { hollow organs }\end{array}$ & Vee formation of geese in flight \\
\hline $\begin{array}{l}\text { E6: Populations are composed of } \\
\text { individual organisms that vary in } \\
\text { their fitness, leading to differential } \\
\text { rates of survival and reproduction } \\
\text { and, therefore, changes in allele } \\
\text { frequency over time. }\end{array}$ & $\begin{array}{l}\text { The emergence of antibiotic } \\
\text { resistance in bacteria }\end{array}$ & $\begin{array}{l}\text { Sickle-cell allele heterozygotes } \\
\text { are more common in areas } \\
\text { where malaria is present }\end{array}$ & $\begin{array}{l}\text { Cryptic coloration in animals: } \\
\text { camouflage to avoid } \\
\text { predation }\end{array}$ \\
\hline $\begin{array}{l}\text { S2: Changes in one component of a } \\
\text { biological system can affect or be } \\
\text { regulated by other components of } \\
\text { the same system. }\end{array}$ & $\begin{array}{l}\text { A mutation in the HTT gene } \\
\text { results in a misfolded } \\
\text { protein leading to the } \\
\text { neurodegenerative disorder } \\
\text { Huntington's disease }\end{array}$ & $\begin{array}{l}\text { Regulation of mean arterial } \\
\text { pressure-changes in } \\
\text { arteriolar diameter impact } \\
\text { arterial pressure }\end{array}$ & $\begin{array}{l}\text { Predator-prey dynamics } \\
\text { (e.g., sea otters are keystone } \\
\text { species that maintain a } \\
\text { healthy kelp community } \\
\text { by eating sea urchins) }\end{array}$ \\
\hline
\end{tabular}

${ }^{a}$ One conceptual element is presented for each core concept. These examples illustrate content addressing each element from courses spanning the molecular, organismal, and ecological scales of biology. 
asked to use the CE Framework to integrate and apply their knowledge of the various examples to investigate the complex problem, thereby creating expert-like networks of knowledge.

Another way to use the CE Framework to build connections across biology courses is to use it to develop an advance organizer (Ausubel, 1960). Advance organizers are educational tools that activate students' prior knowledge and, through scaffolding, facilitate the assimilation of new knowledge and inform students' mental schema about a particular field of study. Multiple studies have shown that student learning can be improved when an advance organizer is used to guide the incorporation of new information (Ausubel 1960, 1978; Barnes and Clawson, 1975; Mayer, 1979; Luiten et al., 1980). In introductory biology, students are introduced to a wide breadth of biological phenomena, which is expanded upon in upper-division courses. Using the CE Framework as a guide, introductory and upper-division instructors could collaborate to generate a simple biology advance organizer that bridges introductory-level biology knowledge and more advanced, discipline-specific knowledge. For example, students could generate a drawing or concept map of an animal cell and its cellular components (e.g., plasma membrane, nuclear membrane, and organelles) in introductory biology and use the CE Framework to discuss how the conceptual elements of structure and function are associated with each cellular component. In a subsequent course, like genetics or cellular biology, students could be asked to recreate or elaborate on their drawings or concept maps to investigate in greater detail how the structure of nucleic acids allows for the function of information flow, storage, and exchange at the molecular scale (i.e., the processes of transcription and translation).

As novice learners develop strategies to organize knowledge through a network of connections, their capacity to think as experts increases (Ambrose et al., 2010). Tools using the conceptual elements, like the examples given above, focus on a common centralized framework that can facilitate development of conceptual understanding by letting students practice organizing complex biological information iteratively as they advance from course to course through a curriculum, thus addressing the need to advance student learning beyond rote memorization (NRC, 1999; Ambrose et al., 2010; Momsen et al., 2010).

\section{Developing and Aligning Learning Objectives and Assessments}

Educators can use the CE Framework in the backward design process (Wiggens and McTighe, 2005) to write learning objectives that guide the development of curricular materials that address gaps in core concept coverage or to make explicit connections among the core concepts. To illustrate the utility of the CE Framework for curriculum design, imagine developing a unit in an introductory biology course that focuses on how fish exchange gases with the surrounding water (example from Table 3). Because structure and function is a primary concept underlying countercurrent gas exchange, the CE Framework could be used to design the learning objectives and associated learning materials so that they address the foundational elements of structure and function. The topic of countercurrent gas exchange would provide the specific information to describe the concept of structure and function, while the individual conceptual elements would provide a framework to define the breadth of coverage. For example, it would be important for students to understand how the structure of the gill arches directs water flow over the gills in a direction opposite that of blood flow and that the blood capillary walls and the gill epithelium are constructed of a single cell layer to allow for diffusion of oxygen from the water into the blood vessel (CE Framework SF1 and SF2). To challenge students to consider how changes in structure may influence function, instructors could expand learning materials to include the developmental stages of fish gills from fry to adult fish (SF3) or how permanent modifications due to disease may alter gill structure and function (SF4 and SF5). To make connections to other core concepts, instructors could have students consider how the expression of genetic information in specific cells corresponds to the development of the gill arches (IFES3) or how blood-oxygen levels are maintained and regulated to provide adequate oxygen for cellular respiration in muscle tissue of the fish (S2). Mapping the information about specific biological topics to the CE Framework as illustrated in this example provides a way to monitor and document whether core concept coverage is comprehensive, regardless of the biological topic taught.

The common language of the CE Framework also lends itself to writing isomorphic learning objectives and assessment questions across different courses. This can make the cross-cutting concepts more transparent to students and support the development of common assessment tools. Building on the examples described in Table 4, we present example isomorphic learning objectives for each selected conceptual element in Table 5 . These isomorphic learning objectives could be modified into isomorphic assessment questions, thus allowing measurement of student learning of the same core concept across a variety of biological phenomena. This approach would allow a department to track students' learning of the core concepts in courses spanning subdisciplines and scales as they progress through a curriculum. The authors have created and are testing a template for developing isomorphic assessment tools using the CE Framework. A manuscript describing this work is in development.

If adopting common or isomorphic assessment tools proves difficult for a department, the CE Framework could also be used as a common rubric for assessing core concept knowledge with data generated from diverse existing assessment tools. When used in this way as part of our local field-testing, the CE Framework yielded consistent scores across multiple graders from a wide variety of student responses. Graders simply scored for the presence or absence of each conceptual element, which allowed us to determine which conceptual elements were addressed and how frequently. Though using the CE Framework as a common rubric for grading student responses from different assessment tools could yield complex data, the benefit to this approach is that it allows individual instructors to retain their existing assessment tools, while simultaneously providing data on student learning that can be compared across multiple courses in a curriculum at the departmental level.

\section{Evaluating Existing Curricula}

Beyond its use to develop instructional materials to support student learning and the development of aligned learning objectives and assessments, the CE Framework may also be used at the department level to map core concept coverage across an entire curriculum. For departments seeking PULSE 
TABLE 5. Examples of isomorphic learning objectives using the conceptual elements ${ }^{\mathrm{a}}$

\begin{tabular}{|c|c|c|}
\hline Selected conceptual element & Isomorphic learning objective 1 & Isomorphic learning objective 2 \\
\hline $\begin{array}{l}\text { TEM5: Biological entities regulate the } \\
\text { synthesis, storage and mobilization of } \\
\text { biological compounds to meet energy } \\
\text { demands. }\end{array}$ & $\begin{array}{l}\text { Students will be able to describe how [the } \\
\text { processes of glycogenesis, glycogenolysis, } \\
\text { and gluconeogenesis] are involved in } \\
\text { regulating [blood glucose levels] to meet } \\
\text { energy demands. }\end{array}$ & $\begin{array}{l}\text { Students will be able to describe how } \\
\text { [rhizobial soil bacteria] are involved in } \\
\text { regulating [nitrogen levels] to meet energy } \\
\text { demands [in host plants]. }\end{array}$ \\
\hline $\begin{array}{l}\text { IFES1: Information exists in many forms and is } \\
\text { relayed within and across biological } \\
\text { molecules, cells, tissues, organisms, } \\
\text { populations, and ecosystems. }\end{array}$ & $\begin{array}{l}\text { Students will be able to explain how } \\
\text { [light-dark cycles] are sensed by [plants], } \\
\text { and result in [a cycle of plant flowering]. }\end{array}$ & $\begin{array}{l}\text { Students will be able to explain how } \\
\text { [increased thyroid hormone levels in a } \\
\text { developing tadpole] result in [activated } \\
\text { thyroid hormone receptors and the onset of } \\
\text { metamorphosis]. }\end{array}$ \\
\hline $\begin{array}{l}\text { SF2: Individual structures can be arranged into } \\
\text { organized units that enable more complex } \\
\text { functions. }\end{array}$ & $\begin{array}{l}\text { Students will be able to describe how [the } \\
\text { arrangement of the myofilaments in the } \\
\text { smooth muscle fibers of hollow organs] } \\
\text { leads to [a reduction in the volume of the } \\
\text { lumen during contraction]. }\end{array}$ & $\begin{array}{l}\text { Students will be able to describe how [the Vee } \\
\text { formation of flight in a flock of geese] leads } \\
\text { to [more efficient, less energetically costly, } \\
\text { flight bouts compared with solo flight]. }\end{array}$ \\
\hline $\begin{array}{l}\text { E6: Populations are composed of individual } \\
\text { organisms that vary in their fitness, leading } \\
\text { to differential rates of survival and } \\
\text { reproduction and, therefore, changes in } \\
\text { allele frequency over time. }\end{array}$ & $\begin{array}{l}\text { Students will be able to explain how [bacteria } \\
\text { with antibiotic-resistant genes] are more } \\
\text { likely to survive and reproduce in the } \\
\text { presence of [antibiotics], increasing the } \\
\text { frequency of [antibiotic-resistant genes] in } \\
\text { the population. }\end{array}$ & $\begin{array}{l}\text { Students will be able to explain how [humans } \\
\text { carrying the allele for sickle cell anemia] are } \\
\text { more likely to survive and reproduce in } \\
\text { the presence of [malaria], increasing the } \\
\text { frequency of [the sickle cell allele] in the } \\
\text { population. }\end{array}$ \\
\hline $\begin{array}{l}\text { S2: Changes in one component of a biological } \\
\text { system can affect or be regulated by other } \\
\text { components of the same system. }\end{array}$ & $\begin{array}{l}\text { Students will be able to predict how decreases } \\
\text { in [sea otter population levels] will impact } \\
\text { [sea urchin and kelp population levels]. }\end{array}$ & $\begin{array}{l}\text { Students will be able to predict how [a } \\
\text { mutated form of the HTT gene] will impact } \\
\text { [the structure and function of the hunting- } \\
\text { tin protein]. }\end{array}$ \\
\hline
\end{tabular}

aTwo isomorphic learning objectives are provided for each of the selected conceptual elements in Table 4. Italicized text in brackets demonstrates the interchangeable nature of the isomorphic learning objectives to address a specific biological phenomenon.

accreditation, the CE Framework can be used in tandem with the PULSE rubrics to identify specific gaps and strengths in their curriculum that they need to complete the PULSE "curriculum alignment" rubric, which measures to what extent the core concepts are covered in the curriculum (Aguirre et al., 2013).

The Vision and Change report offers very general descriptions of the core concepts. When used by individual instructors across a diversity of courses, these general descriptions can produce inconsistent data about core concept coverage that are difficult to align across a curriculum. For example, the components of evolution taught in both a molecular biology and ecology course may be the same, but the language and examples might be different, making it difficult to compare and map exactly what components of evolution are taught in the two courses. Likewise, the components of evolution taught in the two courses may actually be different, but identifying and documenting the differences can be challenging using the Vision and Change report general descriptions. The Vision and Change descriptions alone are not detailed enough for departments to get an accurate profile of which components of the core concepts are being taught across their curricula.

The CE Framework provides the detail needed to address this challenge by providing a way for instructors to be more specific about which components of the core concepts they are teaching. The framework's common language transcends scales and subdisciplines, thus allowing calibration of reports of coverage and learning (and PULSE rubric rankings) across a diversity of courses. This empowers departments to generate accurate and comprehensive concept coverage maps of their general biology curricula.

To support using the framework in this way, we present two conceptual elements sample worksheets, one for individual courses and one for departments in Tables 6 and 7, respectively (see the Supplemental Material for a full set of worksheets). These worksheets allow instructors and departments to use the CE Framework to document which Vision and Change core concepts are addressed in their courses, which elements of those concepts are addressed, and at what biological scales. Using worksheets like these, instructors can characterize existing courses, determine how well they address the core concepts, and, if needed, develop strategies to modify them. Departments can use the information provided by the worksheets to facilitate the kinds of cross-departmental collaborations needed for reform efforts and to support their PULSE rubric self-ratings.

\section{CONCLUSION}

The transformation in undergraduate biology education called for in the Vision and Change report is underway at institutions across the nation (Pape-Lindstrom et al., 2015). As the work of transformation progresses, it has become clear that students, instructors, and departments could benefit from more detailed definitions of the core concepts. The BioCore Guide was an important first step in translating the core concepts into subdisciplinary language. The CE Framework takes a next step by providing detailed definitions that transcend subdisciplines and scales. Definitions that can be used in multiple ways from 
TABLE 6. Sample conceptual elements course inventory for mapping core concept coverage ${ }^{a}$

\begin{tabular}{|c|c|c|c|}
\hline Individual course: pathways and transformations of energy and matter (PTEM) & $\mathrm{Y} / \mathrm{N}$ & Course content/unit & Scale(s) \\
\hline $\begin{array}{l}\text { PTEM1: Energy is neither created nor destroyed, but can be transformed from one } \\
\text { form to another to generate biological activity. }\end{array}$ & & & $\begin{array}{l}\square \text { cell/molec } \\
\square \text { organismal } \\
\square \text { ecosystem }\end{array}$ \\
\hline $\begin{array}{l}\text { PTEM2: Input of energy, which can be from different sources, is needed to build and } \\
\text { maintain biological entities, thereby lowering entropy in the system. }\end{array}$ & & & $\begin{array}{l}\square \text { cell/molec } \\
\square \text { organismal } \\
\square \text { ecosystem }\end{array}$ \\
\hline $\begin{array}{l}\text { PTEM3: Biological entities harness potential energy stored in electrochemical gradients } \\
\text { and released from chemical reactions. }\end{array}$ & & & $\begin{array}{l}\square \text { cell/molec } \\
\square \text { organismal } \\
\square \text { ecosystem }\end{array}$ \\
\hline $\begin{array}{l}\text { PTEM4: Matter is recycled through the rearrangement of chemical bonds in biological } \\
\text { entities. }\end{array}$ & & & $\begin{array}{l}\square \text { cell/molec } \\
\square \text { organismal } \\
\square \text { ecosystem }\end{array}$ \\
\hline $\begin{array}{l}\text { PTEM5: Biological entities regulate the synthesis, storage, and mobilization of } \\
\text { biological compounds to meet energy demands. }\end{array}$ & & & $\begin{array}{l}\square \text { cell/molec } \\
\square \text { organismal } \\
\square \text { ecosystem }\end{array}$ \\
\hline $\begin{array}{l}\text { PTEM6: Many chemical elements can serve as electron donors and acceptors to drive } \\
\text { biological processes. }\end{array}$ & & & $\begin{array}{l}\square \text { cell/molec } \\
\square \text { organismal } \\
\square \text { ecosystem }\end{array}$ \\
\hline $\begin{array}{l}\text { PTEM7: Matter can transfer between the abiotic and biotic components of biological } \\
\text { systems. }\end{array}$ & & & $\begin{array}{l}\square \text { cell/molec } \\
\square \text { organismal } \\
\square \text { ecosystem }\end{array}$ \\
\hline
\end{tabular}

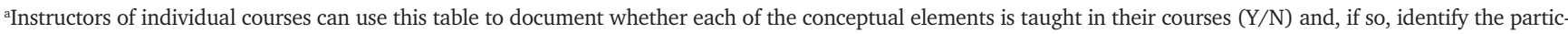
ular content covered and biological scale.

TABLE 7. Sample conceptual elements inventory for mapping core concept coverage across a curriculum ${ }^{a}$

\begin{tabular}{|c|c|c|c|c|c|c|}
\hline Conceptual element courses: & Intro Bio I & Intro Bio II & $\begin{array}{c}\text { Molecular } \\
\text { Biology }\end{array}$ & Physiology & Ecology & $\ldots$ \\
\hline $\begin{array}{l}\text { IFES1: Information exists in many } \\
\text { forms and is relayed within and } \\
\text { across biological molecules, cells, } \\
\text { tissues, organisms, populations, } \\
\text { and ecosystems. }\end{array}$ & $\begin{array}{l}\square \text { cell/molec } \\
\square \text { organismal } \\
\square \text { ecosystem }\end{array}$ & $\begin{array}{l}\square \text { cell/molec } \\
\square \text { organismal } \\
\square \text { ecosystem }\end{array}$ & $\begin{array}{l}\square \text { cell/molec } \\
\square \text { organismal } \\
\square \text { ecosystem }\end{array}$ & $\begin{array}{l}\square \text { cell/molec } \\
\square \text { organismal } \\
\square \text { ecosystem }\end{array}$ & $\begin{array}{l}\square \text { cell/molec } \\
\square \text { organismal } \\
\square \text { ecosystem }\end{array}$ & $\begin{array}{l}\square \text { cell/molec } \\
\square \text { organismal } \\
\square \text { ecosystem }\end{array}$ \\
\hline $\begin{array}{l}\text { IFES2: Genetic information is stored } \\
\text { in nucleic acids (DNA and RNA); } \\
\text { epigenetic information is stored in } \\
\text { proteins that associate with } \\
\text { DNA and in reversible DNA } \\
\text { modifications. }\end{array}$ & $\begin{array}{l}\square \text { cell/molec } \\
\square \text { organismal } \\
\square \text { ecosystem }\end{array}$ & $\begin{array}{l}\square \text { cell/molec } \\
\square \text { organismal } \\
\square \text { ecosystem }\end{array}$ & $\begin{array}{l}\square \text { cell/molec } \\
\square \text { organismal } \\
\square \text { ecosystem }\end{array}$ & $\begin{array}{l}\square \text { cell/molec } \\
\square \text { organismal } \\
\square \text { ecosystem }\end{array}$ & $\begin{array}{l}\square \text { cell/molec } \\
\square \text { organismal } \\
\square \text { ecosystem }\end{array}$ & $\begin{array}{l}\square \text { cell/molec } \\
\square \text { organismal } \\
\square \text { ecosystem }\end{array}$ \\
\hline $\begin{array}{l}\text { IFES3: The process of protein } \\
\text { synthesis results from the flow of } \\
\text { genetic information through } \\
\text { various pathways. }\end{array}$ & $\begin{array}{l}\square \text { cell/molec } \\
\square \text { organismal } \\
\square \text { ecosystem }\end{array}$ & $\begin{array}{l}\square \text { cell/molec } \\
\square \text { organismal } \\
\square \text { ecosystem }\end{array}$ & $\begin{array}{l}\square \text { cell/molec } \\
\square \text { organismal } \\
\square \text { ecosystem }\end{array}$ & $\begin{array}{l}\square \text { cell/molec } \\
\square \text { organismal } \\
\square \text { ecosystem }\end{array}$ & $\begin{array}{l}\square \text { cell/molec } \\
\square \text { organismal } \\
\square \text { ecosystem }\end{array}$ & $\begin{array}{l}\square \text { cell/molec } \\
\square \text { organismal } \\
\square \text { ecosystem }\end{array}$ \\
\hline $\begin{array}{l}\text { IFES5: Organisms transmit genes and } \\
\text { epigenetic information to their } \\
\text { offspring. }\end{array}$ & $\begin{array}{l}\square \text { cell/molec } \\
\square \text { organismal } \\
\square \text { ecosystem }\end{array}$ & $\begin{array}{l}\square \text { cell } / \text { molec } \\
\square \text { organismal } \\
\square \text { ecosystem }\end{array}$ & $\begin{array}{l}\square \text { cell/molec } \\
\square \text { organismal } \\
\square \text { ecosystem }\end{array}$ & $\begin{array}{l}\square \text { cell/molec } \\
\square \text { organismal } \\
\square \text { ecosystem }\end{array}$ & $\begin{array}{l}\square \text { cell/molec } \\
\square \text { organismal } \\
\square \text { ecosystem }\end{array}$ & $\begin{array}{l}\square \text { cell/molec } \\
\square \text { organismal } \\
\square \text { ecosystem }\end{array}$ \\
\hline
\end{tabular}

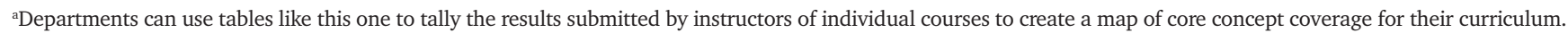

directly supporting student learning through the development of instructional materials, to developing aligned learning objectives and assessments, to evaluating the depth and breadth of core concept coverage across a biology curriculum.
The detailed core concept curricular profiles that can be generated using the CE Framework can be used to guide and monitor reform of both individual courses and a department's entire curriculum. 


\section{ACKNOWLEDGMENTS}

We thank our reviewers, both local and national, for their expertise and guidance, which greatly improved the quality of the CE Framework. We offer special thanks to those who have offered substantial input and review: Caroline Wienhold, Jean Heitz, Jon Breschak, Julie Collins, Kyriaki Chatzikyriakidou, and Jessica TeSlaa. This work was funded by an Undergraduate Science Education grant from the Howard Hughes Medical Institute to the University of Wisconsin-Madison (\#52006959) and by the Wisconsin Institute for Science Education and Community Engagement (WISCIENCE).

\section{REFERENCES}

Aguirre KM, Balser TC, Jack T, Marley KE, Miller KG, Osgood MP, Pape-Lindstrom PA, Romano SL (2013). PULSE Vision \& Change rubrics. CBE Life Sci Educ 12, 579-581.

Ambrose SA, Bridges MW, DiPietro M, Lovett MC, Norman MK (2010). How Learning Works: Seven Research-Based Principles for Smart Teaching, San Francisco, CA: Jossey-Bass.

American Association for the Advancement of Science (2011). Vision and Change in Undergraduate Biology Education: A Call to Action, Washington, DC.

Anderson DL, Fisher KM, Norman GJ (2002). Development and evaluation of the conceptual inventory of natural selection. J Res Sci Teach 39, $952-$ 978.

Ausubel DP (1960). The use of advance organizers in the learning and retention of meaningful verbal material. J Educ Psychol 51, 267-272.

Ausubel DP (1978). In defense of advance organizers: a reply to the critics Rev Educ Res 48, 251-257.

Barnes BR, Clawson EU (1975). Do advance organizers facilitate learning? Rev Educ Res 45, 637-659.

Brooker RJ, Widmaier EP, Graham LE, Stiling PD (2014). Biology, 3rd ed., New York: McGraw-Hill.

Brownell SE, Freeman S, Wenderoth MP, Crowe AJ (2014). BioCore Guide: A tool for interpreting the core concepts of Vision and Change for biology majors. CBE Life Sci Educ 13, 200-211.

Couch BA, Wood WB, Knight JK (2015). The Molecular Biology Capstone Assessment: a concept assessment for upper-division molecular biology students. CBE Life Sci Educ 14, ar10.

D'Avanzo C (2003). Research on learning: potential for improving college science teaching. Frontiers Ecol Environ 1, 533-540.

D'Avanzo C (2008). Biology concept inventories: overview, status and next steps. BioScience 58, 1079-1085.

Dirks C, Knight JK (2016). Measuring college learning in biology. In: Improving Quality in American Higher Education: Learning Outcomes and Assessments for the 21st Century, ed. R Arum, J Roksa, and A Cook, San Francisco, CA: Jossey-Bass, 225-260.

Freeman S, Hamilton H, Hoot S, Podgorski G, Ryan JM, Smith SS, Trent C, Walcott C, Weigle DS (2002). Biological Science, vol. 1, Upper Saddle River, NJ: Prentice Hall.

Goldenfeld N, Woese C (2007). Biology's next revolution. Nature 445, 369

Heitz JG, Cheetham JA, Capes EM, Jeanne RL (2010). Interactive evolution modules promote conceptual change. Evol Educ Outreach 3, 436-442.

Klymkowsky MW (2010). Thinking about the conceptual foundations of the biological sciences. CBE Life Sci Educ 9, 405-407.

Klymkowsky MW, Garvin-Doxas K (2008). Recognizing students' misconceptions through Ed's tools and the Biology Concept Inventory. PloS Biol 6, e3.

Klymkowsky MW, Garvin-Doxas K, Zeilik M (2003). Bioliteracy and teaching efficacy: what biologists can learn from physicists. Cell Biol Educ 2, 155161.
Luiten J, Ames W, Ackerson GA (1980). A meta-analysis of the effects of advance organizers on learning and retention. Am Educ Res J 17, 211-218.

Marbach-Ad G, Briken V, El-Sayed NM, Frauwirth K, Fredericksen B, Hutcheson S, Gao L-Y, Joseph S, Lee VT, Mclver KS, et al. (2009). Assessing student understanding of host pathogen interactions using a concept inventory. J Microbiol Biol Educ 10, 43-50.

Mayer RE (1979). Can advance organizers influence meaningful learning? Rev Educ Res 49, 371-383.

Michael JA (1998). Students' misconceptions about perceived physiological responses. Adv Physiol Educ 19, 90-98.

Michael JA, Richardson D, Rovick A, Modell H, Bruce D, Horwitz B (1999). Understanding students' misconceptions about respiratory physiology. Adv Physiol Educ 22, S127-S135.

Momsen JL, Long TM, Wyse SA, Ebert-May D (2010). Just the facts? Introductory undergraduate biology courses focus on low-level cognitive skills. CBE Life Sci Educ 9, 435-440.

National Research Council (NRC) (1999). How People Learn: Brain, Mind, Experience, and School, Washington, DC: National Academies Press.

NRC (2003). BIO2010: Transforming Undergraduate Education for Future Research Biologists, Washington, DC: National Academies Press.

NRC (2009). A New Biology in the 21st Century. www.nap.edu/ catalog/12764/a-new-biology-for-the-21st-century (accessed 14 October 2016).

Nehm RH, Reilly L (2007). Biology majors' knowledge and misconceptions of natural selection. BioScience 57, 263-272.

Pape-Lindstrom P, Jack T, Miller K, Aguirre K, Awong-Taylor J, Balser T, Brancaccio-Taras L, Marley K, Osgood M, Peteroy-Kelly M, Romano S (2015). PULSE pilot certification results. J Microbiol Biol Educ 16, 127-129.

President's Council of Advisors on Science and Technology (2012). Engage to Excel: Producing One Million Additional College Graduates with Degrees in Science, Technology, Engineering, and Math, Washington, DC: U.S. Government Office of Science and Technology.

Quinn H, Schweingruber H, Keller T (eds.) (2011). A Framework for K-12 Science Education: Practices, Crosscutting Concepts, and Core Ideas, Washington, DC: National Academies Press.

Reece JB, Urry LA, Cain ML, Wasserman SA, Minorsky PV, Jackson RB (2011). Campbell Biology, 9th ed., San Francisco, CA: Pearson Benjamin Cummings.

Scheiner SM (2010). Toward a conceptual framework for biology. Q Rev Biol 85, 293-318.

Smith JI, Combs ED, Nagami PH, Alto VM, Goh HG, Gourdet MAA, Hough CM, Mickell AE, Peer AG, Coley JD, et al. (2013). Development of the biology card sorting task to measure conceptual expertise in biology. CBE Life Sci Educ 12, 628-644.

Smith MK, Wood WB, Knight JK (2008). The Genetics Concept Assessment: a new concept inventory for gauging student understanding in genetics. CBE Life Sci Educ 7, 422-430.

Stamp N, Armstrong M (2005). Using "the power of story" to overcome ecological misconceptions and build sophisticated understanding. Bull Ecol Soc Am 86, 177-183.

Tanner K, Allen D (2005). Approaches to biology teaching and learning: understanding the wrong answers-teaching toward conceptual change. Cell Biol Educ 4, 112-117.

Wiggens G, McTighe J (2005). Understanding by Design, 2nd ed., Alexandria, VA: Association for Supervision and Curriculum Development.

Williams K, Fisher K, Anderson D (2008). Using diagnostic test items to assess conceptual understanding of basic biology ideas: A plan for programmatic assessment. Paper presented at the Conceptual Assessment in Biology Conference II, held 3-8 January, Asilomar, CA. http://bioliteracy .net/CABS.html (accessed 15 October 2016).

Wilson CD, Anderson CW, Heidemann M, Merrill JE, Merritt BW, Richmond G, Silbey DF, Parker JM (2006). Assessing students' ability to trace matter in dynamic systems in cell biology. Cell Biol Educ 5, 323-331.

Woese CR (2004). A new biology for a new century. Microbiol Mol Biol Rev $68,173-186$ 